\title{
Inculcating Noble Values for Pre-Service Teachers
}

\author{
Anita Abu Hasan ${ }^{1}$, Mohd Isa Hamzah² \& Mohd Mahzan Awang ${ }^{2}$ \\ ${ }^{1}$ Teacher Training Institute, Malay Women Campus, Jalan Maktab, Malacca, Malaysia \\ ${ }^{2}$ Faculty of Education, Universiti Kebangsaan Malaysia, Bangi, Malaysia \\ Correspondence: Anita Abu Hasan, Teacher Training Institute, Malay Women Campus, Jalan Maktab, Durian \\ Daun, 75400 Malacca, Malaysia. E-mail: arrissa71@gmail.com
}

Received: April 10, 2014 Accepted: September 26, 2014 Online Published: October 29, 2014

doi:10.5539/ies.v7n11p111 URL: http://dx.doi.org/10.5539/ies.v7n11p111

\begin{abstract}
This study aims to identify the noble values that are being cultivated and practiced in the process of teaching and learning of Ethnic Relations Course for pre-service teachers. Element values investigated including the identity, loyalty, patriotism, tolerance, cooperation and pride as a Malaysian. This quantitative research employs a survey method involving 35 lecturers from five different institutes of teacher education in Malaysia. The participants were selected using stratified random sampling. It was then followed by a simple random sampling. A set of questionnaire was constructed based on the earlier publications and previous empirical research report. Questionnaire data were analyzed using the Statistical Package for the Social Sciences software (SPSS). Findings indicated that the level of lecturers' knowledge in the curriculum for Ethnic Relations Course is high. Overall mean score of lesson plans and teaching preparation by the lecturers for Ethnic Relations Course in applying the noble values are at a very high level. Similarly, the overall findings of the mean score for teaching and learning practices carried out by the lecturers in applying the noble values are also at very high levels. The results of the Pearson Correlation test showed a strong relationship between the lecturers' knowledge and teaching activities, and a strong relationship exists between the lectures' knowledge and learning practices. This means that the cultivation process to promote noble values by the lecturer is associated with knowledge possessed by the lecturers. Indeed data from this study indicated that the curriculum and pedagogical knowledge are prerequisite for the cultivation of noble values. In general, this study demonstrated the importance of early planning done by the lecturers in terms of learning and teaching in order to make the cultivation process of noble values can be achieved.
\end{abstract}

Keywords: noble values, planning, teaching and learning, teaching practice

\section{Introduction}

The term "noble values" means as detailed practice or conduct of human life consisting of positive and civilized attributes which lead to a high culture in our lives. Noble values are not only to be learned, but also, more importantly, to be understood in order to form a human nature with integrity (Sufean 1995, p. 85). Cultivation of noble values is important in the development of the students especially because it is associated with the development of self, personal and family, the environment and the relation to the self and the society.

The cultivation of noble values in educational system started to be emphasized in The New Primary School Curriculum in 1983 and The Integrated Curriculum for Secondary Schools in 1989 (Curriculum Development Center, 1988). The introduction of this curriculum showed that the application of noble values in teaching is an important agenda in the national education system. Each strategy of the cultivation of noble values must be implemented in ordet to enhance the appreciation of the values and the formation of self- discipline in students (Ali \& Eni, 2005, p. 485). It is very important to learn these values but more importantly, these values are to be understood in order to form an integrated and balanced human personality. These days, however, there is a decrease in many of the practices and processes of education that contribute to value creation in our younger generation (Khadijah, 2008). This is because the education system is more focused on the academic success which has resulted in the negligence of affective education. The absence of an appreciation of noble values in education has caused the students to behave more negatively.

\subsection{Problem Statement}

Past studies shows that racial polarization exists at higher educational institutions Higher Education Research 
Institute (2004). A study conducted at a university with a sample that consisted of 6,000 students found that racial polarization exists among university students. Polarization occurs when Malay, Chinese and Indian students hang out only with friends from the same ethnic background only. Students also do not want to share a room in a hostel with friends from different ethnic background, instead they prefer to live with friends who are of the same race with them (IPPTN, 2004, pp. 35-42). In terms of academic activities, most students neither learn nor exchange their lecture notes with students from other study groups, and in terms of co-curricular and students' associations activities that are available, including selecting university of choices, selection of major subjects and specializations, usage of games area and so on, the students are more inclined towards individuals from their own ethnic, religious, cultural and linguistic background, (Ministry of Education, 2004). By right, these problems should not arise as these students had been previously exposed to the noble values even before they enroll in the higher learning institutions.

It is a problem to cultivate noble values in teaching when the teachers are only focusing on delivering the subject contents and ensuring the students' academic achievement (Ainudin \& Abdullah, 2013, p. 287). It is said that the educator are lacking in the mastery of the principles, methods and techniques in teaching moral values, and have little time to carry out the implementation strategy in teaching, as well asnot getting sufficient exposure in relation to the application of the teaching (Ainudin \& Abdullah, 2013, p. 287). The educators are only using the basic principles of implementation of the first principle for the purpose of teaching the students the knowledge of the three basic principles of knowing the value of implementation, understand and appreciate the value (Robiah, 2001, p. 23). Although teachers are knowledgeable about the concept of implementation of noble values, and have the ability to implement the cultivation of noble values in their teaching, the methods used to cultivate the noble values is less organized (Musak, 1993, p. 29). Other constraints in the implementation of the noble values which are faced by educators are: time constraints, lack of knowledge and skills in terms of moral values , heavy workload and lack of appropriate reference materials (Noor-Lela, 2008, pp. 15-28).

In the actual situation, it is easy to plan the cultivation of noble values, however, the implementation process depends on the understanding and appreciation of the concept of noble values and their roles in teaching. Teachers need to understand the importance of self reflection in understanding the importance of absorb, appreciate and apply the practice of values. Realizing this importance, the researcher initiated the study in order to better understand the lecturers' practice of applying the noble values in carrying out the lesson on Ethnic Relations course at pre-service teachers' institutes. Element values to be studied are the identity, loyalty, patriotism, tolerance, cooperation and pride as a Malaysian. Ethnic Relations course refers to the syllabus that is provided for a course offered at the higher educational level. Within the scope of this study, the term higher education refers to Malaysian Institute of Teacher Education (IPGM). The syllabus for the course in this study, the Ethnic Relations course was provided by IPGMs, the Ministry of Education which came into effect beginning from July 2007.

The introductory goal of this course is to create a spirit of camaraderie among students, fostering understanding and cooperation among people and create a better relationship among the younger generation in the country as they are among those who will lead and shape the future of the country. This course focuses on how teacher trainees learn and understand the practices of different ethnic groups and how they interact with each other so as to provide space and opportunities to strengthen ethnic relations in the institution. The term "noble values" refers to the action or special treatment required by a group of people. Value is a perception that determines whether a thing is good or bad. Values in education leads to a positive, honorable and noble values called noble values. Noble values can also mean the details of human practice or conduct in life that contains the positive attributes of a civilization and leads to high culture in life.

Competent lecturers must have the mastery of the content, teaching techniques and positive attitude in conducting the course. Ethnic Relations lecturers should have in-depth knowledge in the field of sociology of ethnic relations. According to the Pedagogical Content Knowledge model (Shulman, 1987), the understanding and knowledge of the instructor is not only dependent on the knowledge of content and curriculum of the course but the instructor must also be knowledgeable in pedagogy related to a particular subject and for specific groups of students. A trainer must be knowledgeable not only in terms of the students and their characteristics, but also in terms of the educational goals as well as planning. Planning is a process that is carried out by a lecturer to implement the teaching. The planning of teaching and learning will involve a process of determining objectives, goals, methods, strategies and activities to be accomplished in the classroom. Careful and systematic planning will produce good and effective teaching. The lecturers who make the preparation to teach should also carry out a diagnosis on their students. This means that lecturers should identify the needs and vulnerabilities of their students. Learning and teaching materials provided are consistent with the variety of the students' abilities. 
Therefore, to ensure maximum learning, lecturers should make a thorough lesson plans to ensure that teaching and learning are fun to do.

To ensure that the process of learning and teaching is effective, it is important to ensure the integration of mental, physical and spiritual activities and experience in the students, especially in order to change the attitudes and behaviors of students as a continuous development. Effective teaching will make the learning process geared toward efforts to produce a well-balanced, harmonious, knowledgeable and ethical individuals. The process of teaching is to change the behavior and conduct of students through the acquisition of knowledge (Esah, 2004). The practice of learning and teaching which is carefully planned will normally produce an effective teaching, especially in an effort to cultivate noble values in students.

\section{Past Studies on the Implementation of Noble Values}

Past studies on noble values have focused on the researches which are related to a balanced and harmonious human development in terms of intellect and character. Below are among the studies that are associated with the studies of noble values:

Nour-Azira's (2001) study aimed to identify whether the lecturers in public tertiary institutions in Malaysia also cultivate noble values in the process of learning and teaching. The study involved 63 respondents who were the academic staff of the Faculty of Engineering Technology in KUiTTHO. The results found that respondents were given priority in applying the characteristics of appreciation of national ethics and noble values in the learning and teaching in the lecture rooms. Noor-Lela's (2008) investigation aimed to explore the practice of the noble values of five accounting teachers in the teaching of Accounting Principles to five secondary schools in the state of Perak. The results showed that all participants in the study had a positive view about the cultivation of noble values in teaching and learning. There are factors which motivated the adoption of noble values in teaching and learning in the classroom, such as receiving encouragement from the Ministry of Education, the principals and encouragement from others. However, there are problems in applying the noble values which were time constraints, lack of knowledge and skills and the lack of reference material.

Bishop's (2002) study was conducted on the perceptions of mathematics teachers in relation to the noble values that were being applied in the teaching of Mathematics. Most mathematics teachers were not aware of the values inherent in this subject and most of them were unaware that they had indirectly implemented the noble values in the classroom teaching. The findings also raised major concerns on the implementation of noble values in the teaching of mathematics in terms of teaching materials and pedagogy. A study conducted by Haywood et al. (2004) suggested a game method called Bingo Game to engage the students in the learning process. By using this method, the teacher were able to make the relevance between teaching noble values and ethics and at the same time making the lesson more interesting and fun for the students. The values espoused in this game include noble values such as integrity, responsibility, trust, etc.

\section{Purpose and Objectives of the Study}

The purpose of the study was to explore and understand the practice of cultivation of noble values by a lecturer in the teaching of Ethnic Relations course in pre-service teachers institutes. The study focuses on the perspective of lecturers in identifying elements that are associated with noble values like lecturers' knowledge, teaching and learning plans, and teaching and learning practiced by the lecturer. The study was also conducted to determine the relationship of the lecturers' knowledge to the lecturers' teaching and learning planning and practices in applying the noble values within the course, especially Ethnic Relation course. Specifically, the objectives of this study are to:

i. Identify the level of knowledge of lecturers in terms of curriculum content in helping the process of adoption of the values in the teaching of Ethnic Relations Course.

ii. Identify the lesson plans and teaching carried out by the lecturers in applying the teaching of noble values in Ethnic Relations course from the perspective of lecturers.

iii. Identify the learning and teaching practices used by the lecturers to cultivate noble values in the teaching of Ethnic Relations course from the perspective of lecturers.

iv. Identify the relationship of the lecturers' knowledge with the planning and practices of teaching and learning carried out by the lecturers in applying noble values within Ethnic Relations course from the perspective of lecturers.

\section{Methodology}

This study employs a quantitative approach by distributing questionnaires to lecturers who teach Ethnic 
Relations course at pre-service teachers institutes. According to Mohd-Majid (1990), survey approach is suitable to be used in a research especially for any research that seeks to explain a phenomenon that is happening. The use of this questionnaire can also save the time, especially in terms of collecting data within a short period of time, while the results can be generalised to the populations accurately and effectively (Chua, 2006, p. 45). The questions in the questionnaire were constructed to include all the matters to be examined. The questionnaire used in this study consists of two parts, Part A and Part B. Part A contains background information on the respondents, while Part B is to get information in identifying the level of knowledge of the lecturers, the planning of teaching and learning as well as teaching and learning practices of lecturers in the values when making teaching and learning process Ethnic Relations course.

A Likert scale of five points was used in the questionnaire and was modified to suit the items being constructed. The rating scale used in this study are shown in Table 1.

Table 1. Likert scale used in the questionnaire

\begin{tabular}{ll}
\hline Construct & The Scale Used \\
\hline Lecturers; Knowledge & Not Very Aware/Not Aware/Less Aware/Aware/Very Aware \\
Teaching and Learning & Not Very Competent/Not Competent/Less Competent/Competent/Highly Competent \\
Plan & \\
Teaching and Learning & Not Implemented At All/Incompletely Implemented/Moderately Implemented/Greatly \\
Practices & Implemented/Completely Implemented \\
\hline
\end{tabular}

A pilot study was conducted at one of the Institute of Teacher Educations in Kuala Lumpur involving a sample of 15 lecturers. Reliability of the lecturers' questionnaire is in the range of 0.6140 to 0.8860 . According to Mohd-Majid (1990), the reliability index of a good questionnaire is more than 0.60 . This means that the questionnaire has high reliability and is suitable for use. The sampling is done by using stratified random sampling covering 35 selected lecturers who were teaching Ethnic Relations course in five Institute of Teacher Education in Malaysia.

\section{Findings and Discussions}

The findings of this study aimed to answer the research questions that are determined based on the objectives set which explores the lecturers' practices in the cultivation of noble values through Ethnic Relations course in the process of learning and teaching in higher education. Descriptive findings are interpreted in five stages as shown in Table 2.

Table 2. Mean score interpretation

\begin{tabular}{ll}
\hline Mean Score & Mean Score Interpretation \\
\hline $1.00-1.89$ & Very Low \\
$1.90-2.69$ & Low \\
$2.70-3.49$ & Moderate \\
$3.50-4.29$ & High \\
$4.30-5.00$ & Very High \\
\hline
\end{tabular}

Source: Department of Planning and Policy Research (2006), Education Development Master Plan, Kuala Lumpur.

Table 3 shows that the overall Mean level of knowledge of the lecturers are at a high level (Mean $=4: 24 ; \mathrm{SD}=$ 0.51 ). Four items are found to have a very high mean values (mean $=4.30$ to 5.00 ) and two items have high mean values (mean $=3.50$ to 4.29 ). These findings indicate that the level of the lecturers' knowledge on the course curriculum is at the high level and good which facilitates learning activities and the lecturers in applying the noble values. 
Table 3. Mean scores and standard deviation of the lecturers' knowledge from the lecturers' perspective

\begin{tabular}{lllcc}
\hline Item & Lecturers' Knowledge & Mean & $\begin{array}{c}\text { Standard } \\
\text { Deviation }\end{array}$ & Interpretation \\
\hline B1. $\quad \begin{array}{l}\text { I have sufficient knowledge to deliver lessons in a systematic } \\
\text { and orderly manner in Ethnic Relations course lectures. }\end{array}$ & 4.45 & 0.50 & Very High \\
B2. $\quad \begin{array}{l}\text { I know a lot about current issues related to ethnic relations. } \\
\text { B3. } \quad \begin{array}{l}\text { I have the knowledge to apply the values of self-esteem } \\
\text { through the topics covered in the Ethnic Relations course. }\end{array}\end{array}$ & 4.60 & 0.61 & Very High \\
B4. $\quad \begin{array}{l}\text { I know how to relate to the current issues related to each } \\
\text { topic in the Ethnic Relations course. }\end{array}$ & 4.57 & 0.55 & Very High \\
B5. $\quad \begin{array}{l}\text { I know the various strategies and the most effective methods } \\
\quad \text { of teaching to associate with historical values. }\end{array}$ & 3.57 & 1.06 & High \\
B6. $\quad \begin{array}{l}\text { I know that the method of group activities can provide } \\
\text { opportunities for students to interact with each other. }\end{array}$ & 3.79 & 1.03 & High \\
\hline & $\quad$ Overall mean & 4.24 & 0.51 & High \\
\hline
\end{tabular}

Lecturers who teach Ethnic Relations course are very knowledgeable in the topics being included in the curriculum, especially the current issues of ethnic relations, including skills in using a variety of teaching methods and strategies in the performance of teaching and learning activities in the classroom as an effort to instill noble values among teacher trainees. The finding is in line with the views of Smith (1986), Shulman (1987) and Ahamad (2012) who stated that pedagogical content knowledge is also considered as the essence of the teachers' knowledge which affects other knowledge components. The same findings had also been demonstrated by several studies done by other researchers related to the lecturers' knowledge, such as past studies by Shahril (2010); Rosni et al. (2010); Abdul-Said et al. (2012), Ahmad (2011) and Zarina (2013).

The analysis in Table 4 shows that the overall mean level of knowledge and teaching lesson plans provided by the lecturers for Ethnic Relations course in cultivating the values are at very high levels (mean = 4:48; $\mathrm{SD}=$ 0.39). Results show that all the items are at their mean values which are very high (mean $=4.30$ to 5.00 ).

Table 4. Mean scores and standard deviation level for learning and teaching planning from the perspective of the lecturers

\begin{tabular}{clccc}
\hline Item & Learning and Teaching Planning & Mean & $\begin{array}{c}\text { Standard } \\
\text { Deviation }\end{array}$ & Interpretation \\
\hline B7. $\quad \begin{array}{l}\text { I prioritize the active participation of teacher trainees during } \\
\text { planning of teaching in the classroom. }\end{array}$ & 4.62 & 0.49 & Very High \\
$\begin{array}{l}\text { I take into account the experience of teacher trainees in their } \\
\text { teaching plans related to the culture of each ethnic groups in } \\
\text { Malaysia. }\end{array}$ & 4.60 & 0.49 & Very High \\
B9. $\quad \begin{array}{l}\text { I plan methods and techniques that encourage collaborative } \\
\text { efforts among various ethnic trainees to create solidarity. }\end{array}$ & 4.40 & 0.55 & Very High \\
B10. $\begin{array}{l}\text { I plan debatable discussion activities to enhance } \\
\text { self-confidence of teacher trainees as Malaysian citizens. }\end{array}$ & 4.40 & 0.55 & Very High \\
B11. $\begin{array}{l}\text { I plan to actively discuss with teacher trainees on issues related } \\
\text { to ethnic relations. }\end{array}$ & 4.57 & 0.55 & Very High \\
B12. $\begin{array}{l}\text { I plan to nurture positive sentiments relating to unity among } \\
\text { teacher trainees from different ethnic background. }\end{array}$ & 4.60 & 0.49 & Very High \\
B13. $\begin{array}{l}\text { I plan to choose suitable learning materials, especially in using } \\
\text { newspaper clippings related to the issue of ethnic relations. }\end{array}$ & 4.40 & 0.55 & Very High \\
\hline & Overall Mean & 4.48 & 0.39 & Very High \\
\hline
\end{tabular}

The results clearly show that a careful planning for learning and teaching which was carried out by the lecturers before they started a session of learning and teaching for the Ethnic Relations course had successfully facilitated 
the process of learning and teaching as well as helped the lecturers in the implementations of noble values among the teacher trainees. This is in line with the study conducted by Maharom (1998), Shahril (2010), Masnora et al. (2011), Rosmilawati (2006) and Ahmad (2011).

The analysis in Table 5 shows that the overall mean value of the standard of teaching and learning by the lecturers in helping their implementations of noble values, is at a very high level (mean $=4: 52 ; \mathrm{SD}=0.39$ ). They have scored a very high mean values in eight items (mean $=4.30$ to 5.00$)$, while two items are at high mean values (mean $=3.50$ to $4: 29$ ).

Table 5. Mean scores and standard deviation of the practices of teaching and learning from the perspective of lecturers

\begin{tabular}{llccc}
\hline Item & Learning and Teaching Practices & Mean & $\begin{array}{c}\text { Standard } \\
\text { Deviation }\end{array}$ & Interpretation \\
\hline B14. $\begin{array}{l}\text { I foster cooperation between the various ethnic trainees during } \\
\text { the learning and teaching process through project assignments. }\end{array}$ & 4.65 & 0.48 & Very High \\
B15. $\begin{array}{l}\text { I allow teacher trainees to argue openly about issues related to } \\
\text { ethnic relations. }\end{array}$ & 4.68 & 0.47 & Very High \\
B16. $\begin{array}{l}\text { I relate historical with current issues that are related to ethnic } \\
\text { relations in this country in my teaching. }\end{array}$ & 4.62 & 0.49 & Very High \\
B17. $\begin{array}{l}\text { I employ question and answer method of teaching when } \\
\text { discussing issues related to ethnic relations. }\end{array}$ & 4.54 & 0.56 & Very High \\
B18. $\begin{array}{l}\text { I use peer group teaching pattern to establish mutual } \\
\text { cooperation among various ethnic trainee teachers. }\end{array}$ & 4.54 & 0.56 & Very High \\
B19. $\begin{array}{l}\text { I encourage interactions among teacher trainees who come from } \\
\text { different ethnic groups when they are performing tasks of } \\
\text { learning and teaching process. }\end{array}$ & 4.25 & 0.61 & High \\
B20. $\begin{array}{l}\text { I use a variety of strategies, methods and techniques that are } \\
\text { effective in promoting the idea of a partnership among trainees } \\
\text { from different ethnic backgrounds. }\end{array}$ & 4.57 & 0.50 & Very High \\
B21. $\begin{array}{l}\text { I use materials from the website and the internet to stimulate the } \\
\text { learning process of the teacher trainees. }\end{array}$ & 4.54 & 0.56 & Very High \\
B22. $\begin{array}{l}\text { Teaching aids are used for video shows that include historical } \\
\text { films. } \\
\text { Reference books on Ethnic Relations course has been used and } \\
\text { has helped the teacher trainees a lot to understand the history, } \\
\text { appreciate the love for the country and realize the elements of } \\
\text { unity. }\end{array}$ & 4.22 & 0.64 & High \\
\hline $\begin{array}{l}\text { Overall Mean } \\
\text { Bigh }\end{array}$ & 0.50 & Very High \\
\hline
\end{tabular}

This finding indicates that the lecturers' level of learning and teaching practices being performed, such as encouraging interactions among teacher trainees from different ethnic groups during tasks performance, fostering cooperation among trainees from various ethnic background during a project assignment and so on, were able to cultivate noble values among the teacher trainees. This is consistent with Abdul-Ghafar's (2003) view which states that lecturers who wisely use proper teaching methods will not only ensure the smooth and effective delivery of a subject but also make a lesson more meaningful as well as fun for the students. This finding is supported by studies of past researchers such as a study by Fazilah et al. (2011); Rosni et al. (2010); Ahmad-Rafaai (2011) and others.

Correlation (Pearson Correlation Product Moment) is used to determine the strength of correlation and relationship between the two variables concerned. Table 6 shows that there is a strong relationship between lecturers' knowledge and the plans for lesson and teaching $(\mathrm{r}=0.612$ and sig. $=0.000<0.01)$. A strong relationship exists between the knowledge of lecturers with teaching and learning practices of lecturers $(\mathrm{r}=$ 
0.623 and sig. $=0.000<0.01)$.

Table 6. Pearson correlation relationship between lecturers' knowledge, teaching and learning plans, and teaching and learning practiced by the lecturer

\begin{tabular}{llll}
\hline Variables & & Planning & Practices \\
\hline \multirow{3}{*}{ Lecturers' knowledge } & Pearson Correlation & $0.612^{* *}$ & $0.623^{* *}$ \\
& Sig.(2-tailed) & 0.000 & 0.000 \\
& $\mathrm{n}$ & 35 & 35 \\
\hline
\end{tabular}

** Correlation is significant at the 0.01 level (2-tailed).

* Correlation is significant at the 0.05 level (2-tailed).

The findings of the analysis found that the more knowledgeable the lecturers are, especially with regard to issues of ethnic relations, the better the preparation and planning of learning and teaching practices in learning and teaching of Ethnic Relations course. The amount of knowledge possessed by the lecturers play an important role in influencing the planning of learning and teaching as well as learning and teaching practices of the lecturers in the classroom as they apply the cultivation of noble values through Ethnic Relations course.

The lecturers are not only highly knowledgeable in the course curriculum but also knowledgeable about the issues of ethnic relations and have the skills in using a variety of teaching methods. This clearly shows that lecturers' knowledge play an important role in influencing the planning of learning and teaching and learning practices and teaching style in the classroom in order to cultivate noble values through Ethnic Relations course. This finding is supported by studies conducted by Shahril (2010); Rosni et al. (2010); Abdul-Said et al. (2012), Ahmad (2011) and Zarina (2013).

In-depth knowledge of the lecturers on topics contained in the curriculum, especially knowledge about current issues of ethnic relations and skills using a variety of teaching methods and strategies have helped the infusion of values to create unity among teachers. Even the practice of lecturers who adopt the methods of cooperation between trainee teachers when making project assignments and encourage interaction among trainee teachers of different ethnic groups, have tighten the ties and bonds between trainee teachers. Significantly, it constitute positively to the implementation process of element values to create unity among the trainee teachers. This finding is consistent with the view of Cochran et al. (1993) and Ahamad (2012) on the importance of content knowledge and understanding of a subject in determining the ability of teachers to transfer knowledge to students.

Infusion of good moral values made by the lecturer in Ethnic Relations course is more focused on the formation of attitudes of trainee teachers to receive their friends from other races. After following the teaching and learning of Ethnic Relations course, infusion of moral values among trainee teachers who are from different religions, races and culture had been successful in fostering attitudes of respect, cooperation, tolerance and even mutual understanding among the trainee teachers. This finding clearly indicates that the government's efforts to make the education system as a medium to create positive attitude of the students is particularly successful in creating a society that can live in unity and love for the country. This finding is reinforced by a study by Nazri et al. (2006), Khalim et al. (2010), Zulkifli (2010), Ahmad (2011), Fazilah et al. (2011), and Hamidah et al. (2011).

\section{Conclusion}

The results of this study show a very high and good overall level of the practices being applied in the cultivation of noble values by of the lecturers through the Ethnic Relations course in the process of learning and teaching in pre-service teachers' institutes. These findings clearly indicate that the level of implementation of noble values that is carried out by the lecturers during the Ethnic Relations course is influenced by the lecturers' knowledge, lecturers' lesson plans and teaching style as well as teaching and learning practices. The high mean score as well as the support from the findings of other researchers clearly show that the practices of applying noble values are implemented by the lecturers at the tertiary level. Lecturers are also responsible for increasing the quality of their teaching by varying the use of teaching methods in the classroom and at the same time to always be ready to innovate new approaches in learning and teaching, particularly relating to the methods, techniques, strategies and approaches in order to apply the noble values through the process of learning and teaching. Early planning, especially before using an appropriate technique, would help in the process of adoption of noble values. This finding is supported by Musak's (1993) study, which says that even though teachers are knowledgeable about the 
concept of cultivating the ability to perform in teaching, if the methods used to perform the cultivation of noble values are less organized, then the application may not be fully successful.

\section{References}

Abdul-Ghafar, B. M. (2003). Principles and Practices of Teaching. Kuala Lumpur: Utusan Distributors Sdn Bhd.

Abdul-Said, B. A., Mohd-Yusof, B. A., Baharom, B. M., \& Shukri, B. Z. (2012). Influence of Pedagogical Knowledge and Content against Teacher Efficacy in Teaching Economics. Sabah: Universiti Malaysia Sabah.

Ahamad, B. R. (2012). History Curriculum Assessment Lower Secondary Form 2 (Ph.D. thesis, Universiti Kebangsaan Malaysia, Selangor).

Ahmad, A. B. S. (2011). The Effectiveness of Teaching and Learning History based on the Perspectives on Cultural Diversity against the Formation of National Integration (Ph.D. thesis, Universiti Kebangsaan Malaysia, Selangor).

Ahmad-Rafaai, B. A. (2011). The Effectiveness of Teaching History based on Learning Goals, Readiness to Learn, Understanding of Concepts and Mapping History (Ph.D. thesis, Universiti Kebangsaan Malaysia, Selangor).

Ainudin, B. Y., \& Abdullah, B. M. R. M. I. (2013). Perception of Students against the Application of Noble Values in the Teaching of Teacher from Technical Stream. Graduate Seminar in Education. Fakulti Pengajian Pendidikan. Selangor: Universiti Putra Malaysia.

Ali, B. S., \& Eni, E. B. Y. (2005). Appreciation of Noble Values towards the Formation of Students Discipline. Proceedings of Education JPPG, 485-495. Johor: Kolej Universiti Teknologi Tun Hussein Onn.

Bishop, A. J. (2002). Research, Policy and Practice; The case of values. Proceedings of the $3^{\text {rd }}$ International MES Conference (pp. 1-7). Copenhagen. Centre for Research in Learning Mathematics.

Chua, Y. P. (2006). Basic Statistical Research Methods and Statistics Research. Kuala Lumpur: MacGraw Hill.

Cochron, K. F., De Ruiter, J. A., \& King, R. A. (1993). Pedagogical content knowing: An intergrative model for teacher preparation. Journal of Teacher Education, 44(4), 263-272. http://dx.doi.org/10.1177/0022487193044004004

Esah, B. S. (2004). Introduction to Pedagogy. Johor: Universiti Teknologi Malaysia.

Fazilah, B. I., Mashitoh, B. Y., \& Mat B. T. (2011). Teaching and learning methods for Ethnic Relations Course: Interactive or destructive. Selangor: Universiti Kebangsaan Malaysia.

Hamidah, B. A. R., Norlin, B. A., Nor, A. B. N., Norashikin, B. M., Rozianan B. S., \& Shah R. B. A. W. (2011). Kajian Tinjauan Hubungan Etnik dalam kalangan pelajar Tahun Satu. Johor: Universiti Teknologi Malaysia. Jurnal Teknologi, 54(Sains Sosial), 65-76.

Haywood, M. E., McMullen, D. A., \& Wygal, D. E. (2004). Using games to enhance student understanding of professional and ethical responsibilities. Issues in Accounting Education, 19(1), 85-99. http://dx.doi.org/10.2308/iace.2004.19.1.85

Institute for Research on Higher Education. (2004). Study of Ethnic Integration in Public Higher Education Institutions. Pulau Pinang. Universiti Sains Malaysia.

Khadijah, B. M. Y. (2008). The formation of pro social behavior and human quality. Paperwork for National Seminar on Morality and Moral Education. Department of Educational Foundations and Humanities. Faculty of Education. Kuala Lumpur: Universiti Malaya.

Khalim, B. Z., Taip, B. A., \& Zulkifli, B. M. (2010). Kesan penggunaan Modul Hubungan Etnik terhadap sikap perkauman dalam kalangan pelajar Kursus Hubungan Etnik. Bangi: Pusat Pengajian Siswah, Universiti Kebangsaan Malaysia.

Maharom, B. M. (1998). Analysis on historical thinking skills in curriculum materials forlower secondary level (Unpublished Dissertation Master of Education). Kuala Lumpur: Universiti Malaya.

Masnora, B. S., \& Nur, Z. B. H. K. (2011). Monitoring the effectiveness of teaching and learning in Polytechnic of Port Dickson-A case study in the Department of Electrical Engineering.

Ministry of Education. Kementerian Pelajaran Malaysia. (2004). Monitoring Report on the Effectiveness of History Subject Curriculum in Sarawak and Sabah. Kuala Lumpur. 
Mohd-Majid, B. K. (1990). Research Methods in Education. Kuala Lumpur: Dewan Bahasa da Pustaka.

Musak, B. M. (1993). Moral values in the Malaysian intergrated secondary school currivulum: A survey on the teachers'perceptions and abilities (Disertasi Doktor Pendidikan (Ed.D), University of South Dakota).

Nazri, B. M., Zulkifli, B. M., Nik, Y., B. M., \& Aminuddin, B. B. (2006). Pelaksanaan Kursus Titas dan Hubungan Etnik di IPTA: Pengalaman Universiti Kebangsaan Malaysia. Pusat Pengajian Umum. Selangor: Universiti Kebangsaan Malaysia.

Noor-Lela, B. A. (2008). The practice of adoption of noble values among accounting teachers in the teaching of Accounting Principles (Ph.D. thesis, Universiti Kebangsaan Malaysia, Selangor).

Nour-Azira, B. N. (2001). Study on the Implementation of Noble Values across the Curriculum in KUiTTHO: A Review among Lecturers from the Faculty of Engineering Technology. Johor: Kolej Universiti Teknologi Tun Hussein Onn

Perkembangan Kurikulum. (1988). Noble values in KBSM: Challenges for educators. Kuala Lumpur: Kementerian Pendidikan Malaysia.

Planning and Policy Research. (2006). Education Development Master Plan Bahagian Perancangan dan Penyelidikan Dasar Pendidikan. Kuala Lumpur.

Robiah, B. K. H. (2001). Research on the instillment of noble values in the teaching of the Malay language in secondary schools in Hulu Langat, Selangor (Unpublished Ph.D. thesis). Selangor: Universiti Kebangsaan Malaysia.

Rosmilawati, B. A. R. (2006). Assessing Teaching against Bachelor of Technical and Vocational Education in Teaching Programs in Technical Schools (Master of Education thesis, University College of Technology Tun Hussein Onn, Johor).

Rosni, B. Z. S., \& Rohayah, B. A. (2010). Teaching practice of the Technical Teachers in Technical Secondary School of Commerce Johor Bahru according to Bloom's Cognitive Level. Faculty of Education. Johor: Universiti Teknologi Malaysia

Shahril, C. B. M. (2010). The Effectiveness of Teacher Instructional Practices: A study on some secondary schools in Malaysia. Faculty of Education, Kuala Lumpur: Universiti Malaya.

Shulman, L. (1987). Knowledge and Teaching: Foundation for a New Reform. Harvard Educational Review, $57(1), 1-22$.

Smith, F. (1986). Insult to intelligence: The bureaucratic invasion of our classroom. New York: Portsmouth Heinemann.

Sufean, B. H. (1995). The teaching of values in the curriculum (2nd ed.). Pengajaran nilai dalam kurikulum. Edisi Kedua. Petaling Jaya: Siri.

Zarina, B. M. Y. (2013). Evaluating the Implementation of Historical Thinking Skills (KPS) in the Upper Secondary Level (Ph. D. Thesis, Universiti Kebangsaan Malaysia, Selangor).

Zulkifli, B. S. (2010). Sikap pelajar terhadap Mata Pelajaran Hubungan Etnik. Jurnal Penyelidikan Cerana Bil 5. Institut Pendidikan Guru Kampus Tun Hussein Onn. Johor: Batu Pahat.

\section{Copyrights}

Copyright for this article is retained by the author(s), with first publication rights granted to the journal.

This is an open-access article distributed under the terms and conditions of the Creative Commons Attribution license (http://creativecommons.org/licenses/by/3.0/). 